\title{
Probable intensity of Sylhet city from an event like 1918 Srimangal earthquake
}

\author{
Sudipto Kumar Das ${ }^{1} \cdot$ Md. Nazmul Hasan ${ }^{1} \cdot$ Md. Jahir Bin Alam ${ }^{1}$
}

Received: 29 July 2019 / Accepted: 13 November 2019 / Published online: 18 November 2019

(c) Springer Nature Switzerland AG 2019

\begin{abstract}
An intensity map plays an important role and is required for construction, so in this study, we presented a map of intensity for every ward of the city of Sylhet. Another objective of this research is to create a methodology to develop the intensity map for Sylhet with the equation readily available. Sylhet is Bangladesh's most seismically susceptible region owing to its location in the southeast portion of Dauki fault. In the last 101 years, almost 184 massive earthquakes in the Sylhet area have taken place between the magnitude of 4 and 7.2. Among these earthquakes, the 1918 earthquake of Srimangal was selected as it was the first one to be felt and recorded in Bangladesh as a destructive earthquake. The probable intensity map for the Sylhet city of Bangladesh using Geographic Information Technology has been made considering the 1918 Srimangal earthquake as a scenario case. For this purpose, 157 boreholes data were collected to calculate the shear wave velocity. The SPT-N value of most of the borehole data is as deep as $15 \mathrm{~m}$. Then it was converted to the required amount at a depth of $30 \mathrm{~m}$. In addition, Shear wave velocity was also converted to the Peak Ground Acceleration using McGuire equation. The highest Amplification Factor was used among the three equations for converting the Peak Ground Acceleration into the Surface Acceleration. Finally, the Surface Acceleration has been converted into the Modified Mercalli Intensity scale to make it simple to comprehend. The findings show that the minimum and maximum Peak Ground Acceleration are both $0.164 \mathrm{~g}$ and $0.175 \mathrm{~g}$, and the Amplification Factors vary between minimum and maximum from 2.027 to 3.40 . Also, surface acceleration ranges from 0.347 to $0.578 \mathrm{~g}$. The intensity is estimated at 27 wards in the city of Sylhet. This demonstrates that $81.48 \%$ of the intensity IX areas are impacted and $18.52 \%$ of the intensity VIII areas as a scenario case for the Srimangals 1918's earthquake. Since the town of Sylhet does not have an intensity map, this research aims to prepare a map for all Sylhet wards.
\end{abstract}

Keywords Sylhet Region - Shear wave velocity (SWV) - Peak ground acceleration (PGA) - Amplification factor (AF) . Surface acceleration (SA) $\cdot$ Modified Mercalli intensity (MMI)

\section{Introduction}

Sylhet is Bangladesh's most significant northeast district (Fig. 1). This region is at least 50 times the population rise as compared to that of 1918. It comprises 27 wards (Fig. 1) with more than a million inhabitants. This area is the most vulnerable to an earthquake because of the geological location. The region of Sylhet is located on Dauki Fault's southeastern portion (Fig. 2) and earthquakes are quite often encountered, which in the past have caused great destruction. Several earthquakes such as the Gujarat earthquake 2001 with magnitude 6.9 [1], Kashmir earthquake 2005 with magnitude 7.6 [2], have assaulted this area in latest times [3]. The 8.0 magnitude earthquake in the northwestern portion of India in 1897 caused severe damage, and 1542 individuals were killed [3]. Bilham et al.

Sudipto Kumar Das, sudipto9747@gmail.com; surjo9747@student.sust.edu|'Department of Civil and Environmental Engineering, Shahjalal University of Science and Technology, Sylhet 3114, Bangladesh. 


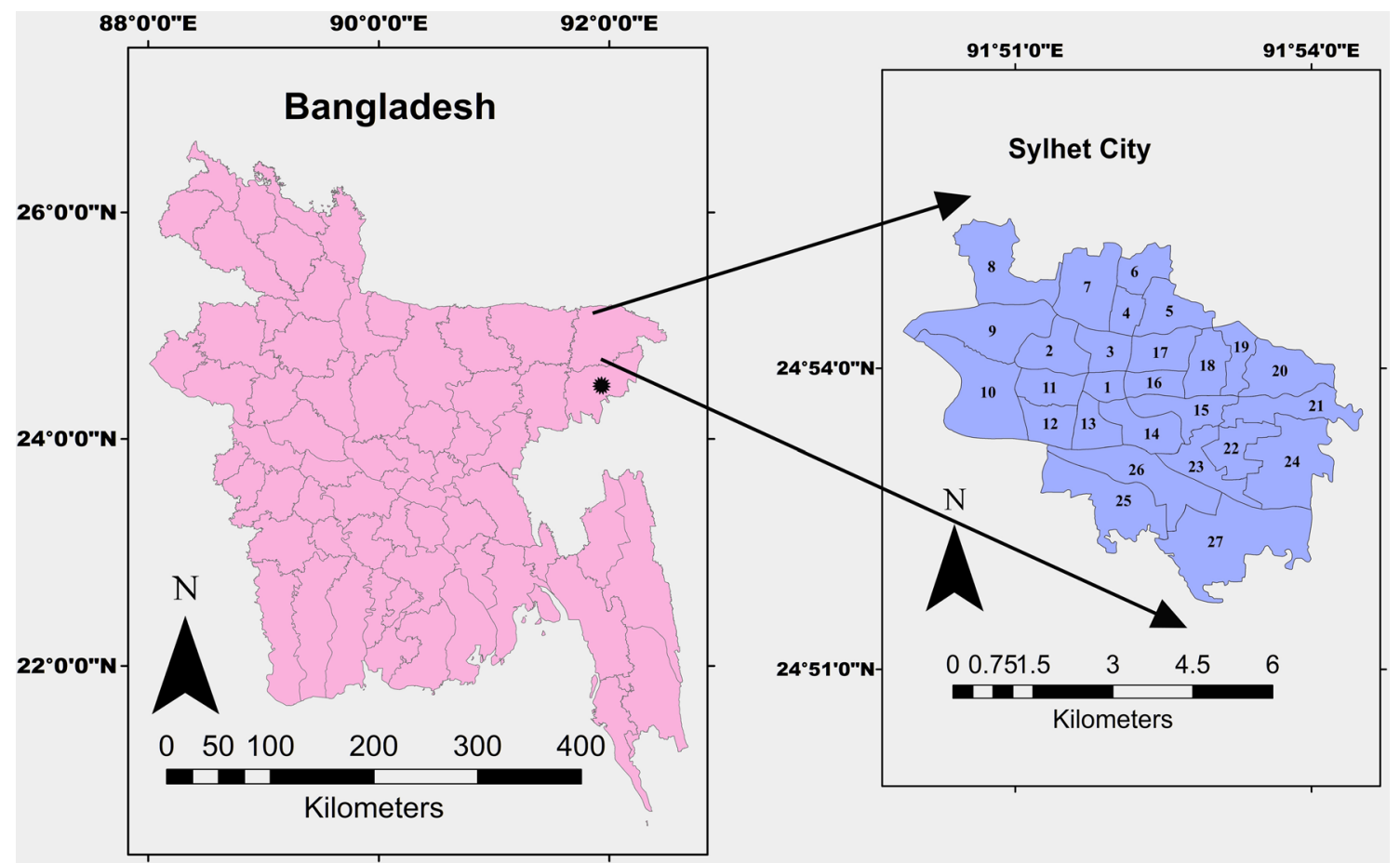

Fig. 1 Location map of study area (Numbers denote ward no of Sylhet city) and the epicenter position of the Srimangal earthquake in 1918 is represented by star

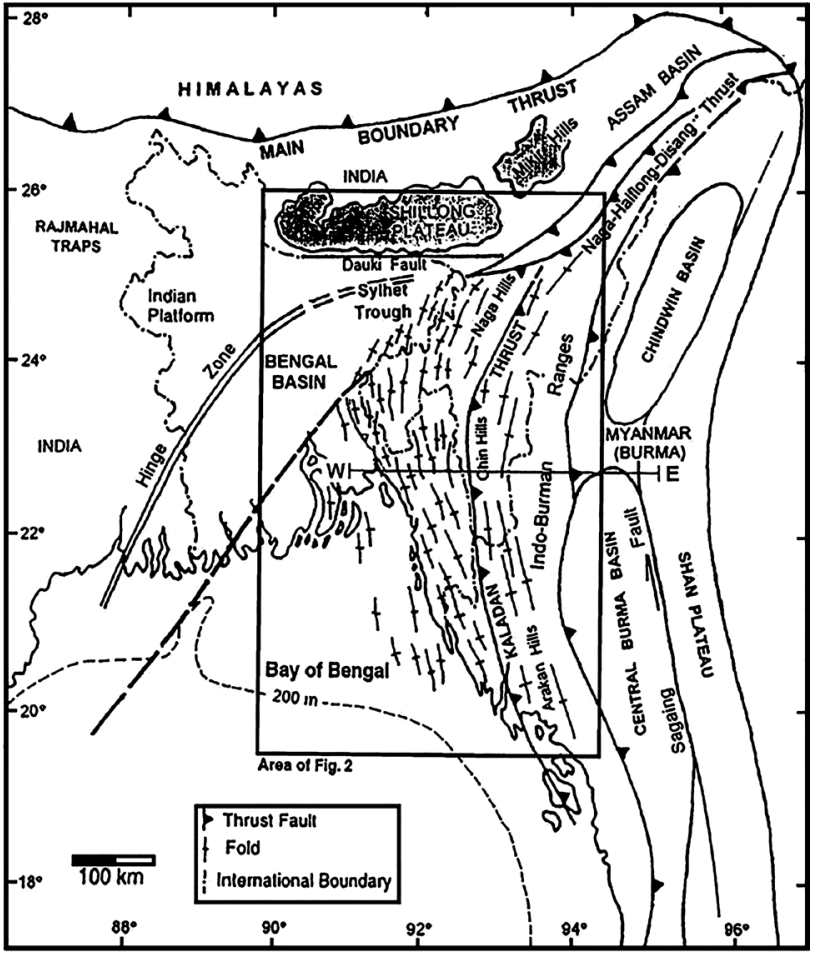

Fig. 2 Tectonic map of Bangladesh's North-East Region shows that the Dauki fault goes through the southern shore [13]
[4] noted that a significant earthquake is highly likely to happen in the Himalayas because of the distinction between the accumulation of energy in this region and the historical earthquake. So, the next great earthquake may happen in this region at any moment is a cause for major concern.

An attenuating law for Peak Ground Acceleration (PGA) is required in order to estimate the seismic hazard and intensity at any site. In this research, McGuire's (1978) attenuation law was applied because Bangladesh soil is similar to the sort of soil that the McGuire legislation uses and with some transformation, the values of the MMI (Modified Mercalli intensity) scale were achieved. The probability of intensity the analysis will be used not only for the likely structural damage but also for the planning and construction site. Furthermore, this evaluation sends a message to the community to correctly use building code.

\section{Regional tectonics}

Bangladesh, due to its geological situation as the northeast part of the active Indian sub-continent (Fig. 2), is critically vulnerable to earthquakes $[5,6]$. Molnar and Tapponnier (1975) state that the Indian subcontinent has pushed the Eurasian plates at a rate of $5 \mathrm{~cm}$ per year northwards over the past 40 million years $[3,7]$. 
Bilham et al. (2001) have recently pointed out that a big earthquake is highly likely to happen around the Himalayans because of the distinction between energy accumulations $[4,8]$. One of the most highly active seismic areas of the globe can be considered as the Himalayan arc [9]. The Shillong plateau in North-East India (Fig. 2) and its neighboring syntax are one of the most volatile areas on the Alpine-Himalayan belt between the two current structures and three significant size earthquakes in the last two centuries [10]. Currently, in the Himalaya-Shillong Plateau region, the most southwest thrust could take place at the southern edge of the Dauki fault [11]. The Shillong Plateau is thought to have a thrusting plane beneath it, and it is enduring to the south, with an especially seismic status, that refutes the notion of vertical tectonism along the Dauki fault [12]. Also, the presence of the Dauki fault scheme in the East and South-East Assam area with Hafong's fault, Naga and Disang's thrust (Fig. 2) puts the Sylhet area at risk $[13,14]$. The position of Dauki Fault with tectonic details surrounds is illustrated in Fig. 2.

In the Sylhet Region of Bangladesh, the 8th July 1918 Srimangal earthquake is one of the most destructive earthquakes that have taken place in this century. In the Ballisera hills near Kalighat, the macroseismic epicenter is situated $6 \mathrm{~km}$ south of Srimangal, $91.80^{\circ}$ north and $24.25^{\circ}$ east (Fig. 1) [8]. The main shock that took approximately $12 \mathrm{~s}$ affected the entire community devastatingly [12]. The focus of the earthquake was 12-14 km beneath the earth's surface, according to Stuart [15]. The site was also categorized as a slight earthquake by Gutenberg and Richter [16], a magnitude 7.6 (Class b, i.e. depth $<60 \mathrm{~km}$ ) [15]. Table 1 presents the significant earthquakes affecting Sylhet since the end of the previous century.

While a number of inquiries have been carried out in Sylhet city, such as building loss estimates owing to seismic vulnerability, but no substantial study has been carried out on every word of Sylhet city in order to prepare the intensity map.

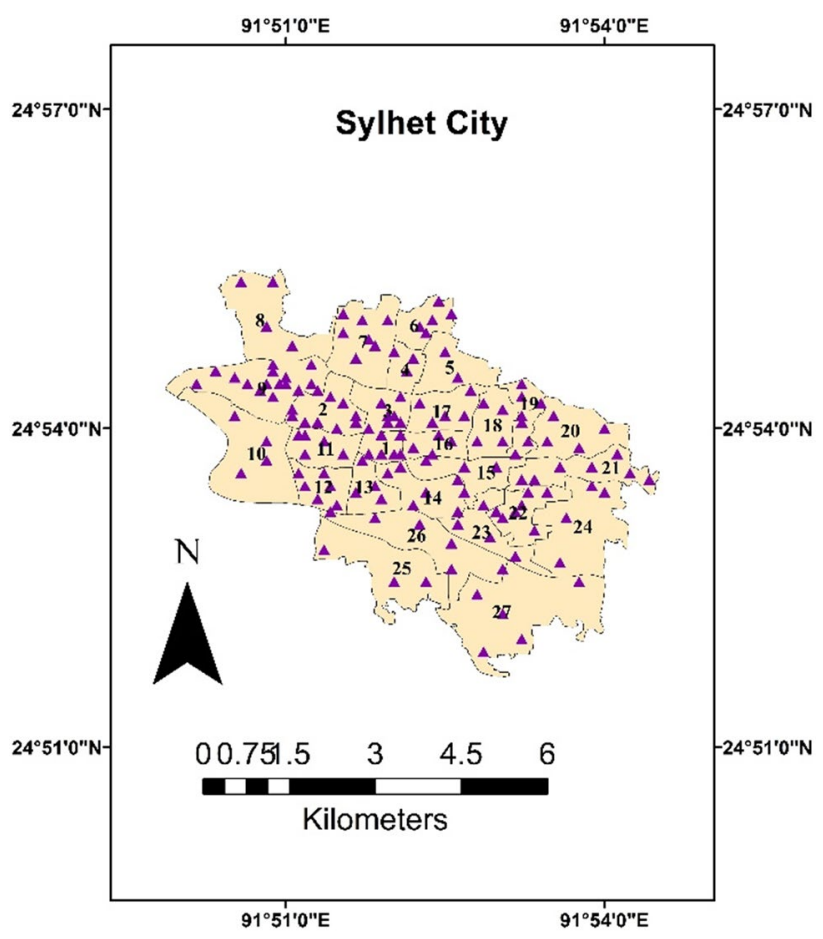

Fig. 3 Location of borehole data for 27 wards of Sylhet city

\section{Estimation of shear wave velocity (SWV) from SPT value}

In site investigation, the SPT-N value is significant as well as the shear wave velocity calculation. The velocity of the shear wave is the mechanical character of the soil [17]. In situ testing, it is always preferable to determine the velocity of the shear wave. However, owing to the price of instruments, and the elevated noise level connected with this experiment in urban regions, it is not always possible. So, the velocity of the shear wave is calculated via an indirect method. The shear wave velocity of uncorrected SPT-N can be calculated with many empirical equations. In this study, three empirical equations from Lee [18] is used because other equations try to concentrate on a single relation between uncorrected SPT-N and shear wave velocity in every soil. For the calculation of the shear wave
Table 1 Some historic quakes at Sylhet with magnitude, intensity, epicentral distance, and focal depth [3]

\begin{tabular}{lllcl}
\hline Name of the earthquake & Fault & Magnitude & Distance (KM) & $\begin{array}{l}\text { Focal } \\
\text { depth } \\
(\text { KM) }\end{array}$ \\
\hline 1869 Cachar Earthquake & Tripura & 7.5 & 92 & 56 \\
1885 Bengal Earthquake & Bogura & 7.0 & 234 & 72 \\
1897 Great Indian Earthquake & Assam & 8.7 & 151 & 60 \\
1918 Srimangal earthquake & Sub-Dauki & 7.6 & 71 & 14 \\
\hline
\end{tabular}


velocity of SPT-N value 157 borehole information were gathered. The bore hole position is shown in Fig. 3. However, Lee concentrated on various soil types, such as sand, silt, and clay, and those equations are of good value [19]. These equations are

For sand $\mathrm{V}_{\mathrm{s}}=57.4 \mathrm{~N}^{0.49}$

For silt $\mathrm{V}_{\mathrm{s}}=105.64 \mathrm{~N}^{0.32}$

For clay $\mathrm{V}_{\mathrm{s}}=114.43 \mathrm{~N}^{0.31}$

where $\mathrm{N}=$ Un-corrected SPT-N value.

\section{Estimation of shear wave velocity (SWV) at $\mathbf{3 0} \mathrm{m}$ depth}

Most data include a ground profile up to a depth of 15 meters; however, an important parameter used for classification of the site is the average wave velocity of the top $30 \mathrm{~m}$ of the earth. So, it is necessary to have a conversion at the shear wave velocity at $30 \mathrm{~m}$, by using the shear wave velocity at $15 \mathrm{~m}$. The unified building code (UBC) and International Building Code (IBC) provide a comparable strategy with respect to the speed of the shear waves at a depth of $30 \mathrm{~m}$ [20]. Table 2 provides additional details. Thus, the shear wave velocity at a depth of $30 \mathrm{~m}$ is calculated by Boore's law with the assistance of the average shear wave velocity of $15 \mathrm{~m}$ [21].

$\log \bar{V}_{s}(30)=a+b \log \bar{V}_{s}(\mathrm{~d})$

$\mathrm{a}$ and $\mathrm{b}$ are regression co-efficient. $\mathrm{a}=0.013795$ and $\mathrm{b}=1.0263$ for $15 \mathrm{~m}$ depth. $\bar{V}_{s}(\mathrm{~d})=$ Average shear wave velocity up to $15 \mathrm{~m}$ depth.

The estimated speed of the shear wave is quite low than the actual rate. While the shear wave velocity is associated with surfaces acceleration, low shear wave provides elevated acceleration on the surface. So, the calculated shear wave velocity will thus fulfill most of the critical requirements.

Table 2 Definition of NEHRP site classes in term of average shear wave velocity to $30 \mathrm{~m}[22,23]$. Rock-type from Martin and Diehl [24]

\begin{tabular}{lll}
\hline Site class & Rock type & Range of $\mathrm{V}_{\mathrm{s}}(30)$ \\
\hline A & Hard rock & $>1500 \mathrm{~m} / \mathrm{sec}$ \\
B & Rock & $760-1500 \mathrm{~m} / \mathrm{s}$ \\
C & Very dense soil and soft & $360-760 \mathrm{~m} / \mathrm{s}$ \\
& $\quad$ rock & \\
D & Stiff soil & $180-360 \mathrm{~m} / \mathrm{s}$ \\
E & Soft soil & $<180 \mathrm{~m} / \mathrm{s}$ \\
\hline
\end{tabular}

The approximated shear wave speed is between 180 and $360 \mathrm{~m} / \mathrm{s}$ at $30 \mathrm{~m}$ depth in this research, so site category $D$ is selected.

\section{Estimation of peak ground acceleration (PGA)}

The velocity of the shear wave has also been associated with the acceleration of the PGA. The PGA is an acceleration which takes place on the surface of the ground owing to a shaking of the base. Everywhere, the value of PGA is not equal. The PGA value varies with parameters such as the magnitude of the earthquake, the distance from hypocenter and soil, velocities of the shear wave. For Bangladesh, a lack of strong-motion data has not led to a PGA attenuation law being developed. The attenuation by McGuire [25] was employed in this study as the land in Sylhet is similar to what the McGuire legislation applies to [26]. The following is the relationship

$y=0.0306 e^{0.89 M} r^{-1.17} e^{-0.2 s}$

where $y=$ Peak ground acceleration, $M=$ surface wave magnitude. In this study 1918 Srimangal earthquake is considered which has magnitude of 7.6. $s=0$ for rock and $s=1$ for alluvial, $r=$ Hypo central distance $=\sqrt{d^{2}+h^{2}}$, $\mathrm{d}=$ distance from the epicenter to the location, $\mathrm{h}=$ focal depth, assumed $14 \mathrm{~km}$ for Srimangal earthquake.

Figure 4 indicates the value of peak ground acceleration. Srimangal earthquake was selected in this research because it provides PGA higher than other shocks. Google earth software measures the distance from the epicenter to the spot.

\section{Estimation of amplification factor (AF)}

The bed-level PGA and the surface-level PGA are not identical. PGA is called surface acceleration at surface level [27]. Surface acceleration is higher than peak ground acceleration. Therefore, an equation is necessary for generating an amplification factor that can transfer the PGA value to the surface acceleration. The surface acceleration is generated by three equations, and among them, the largest amplification factor is taken. The outcome of the large amplification value for the 27 sylhet city wards is shown in Fig. 5 . The site amplification is estimated by applying the relations between the average shear wave velocity (AVSdepth) and amplification factor (Af) in areas where shear wave profiles are available by Eq. 6 [28].

$\log \left(A_{f}\right)=-0.734 * \log \left(A V S_{\text {depth }}\right)+1.98$ 


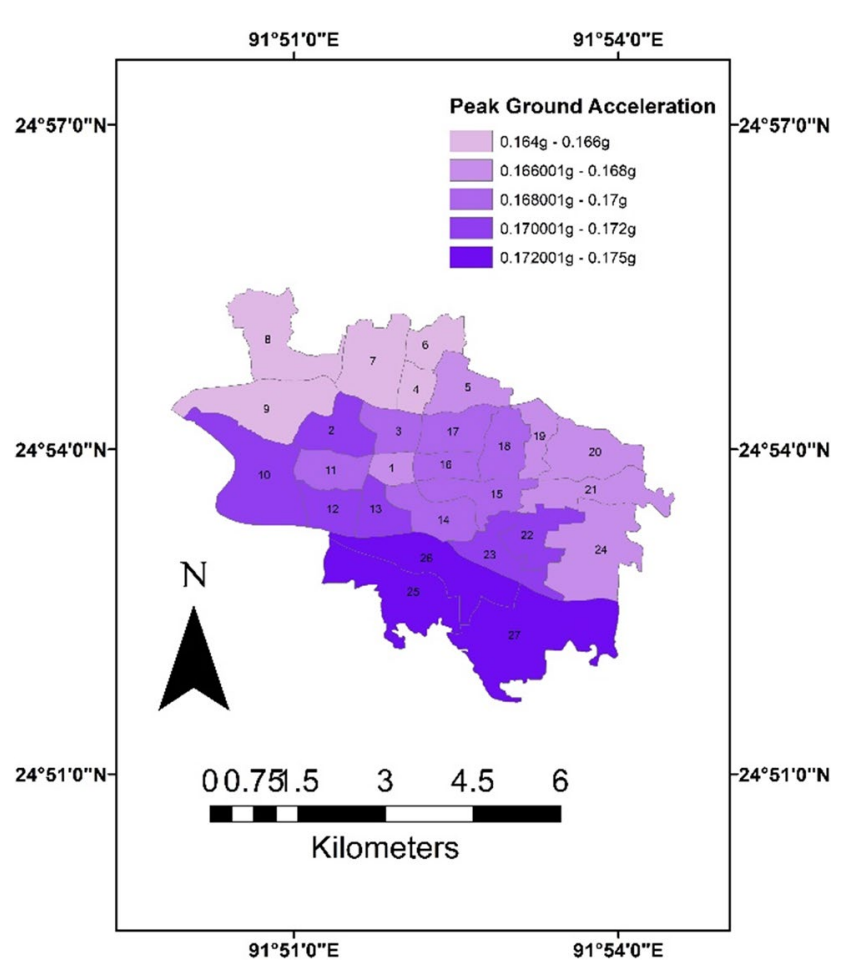

Fig. 4 PGA value for 27 wards of Sylhet city corporation

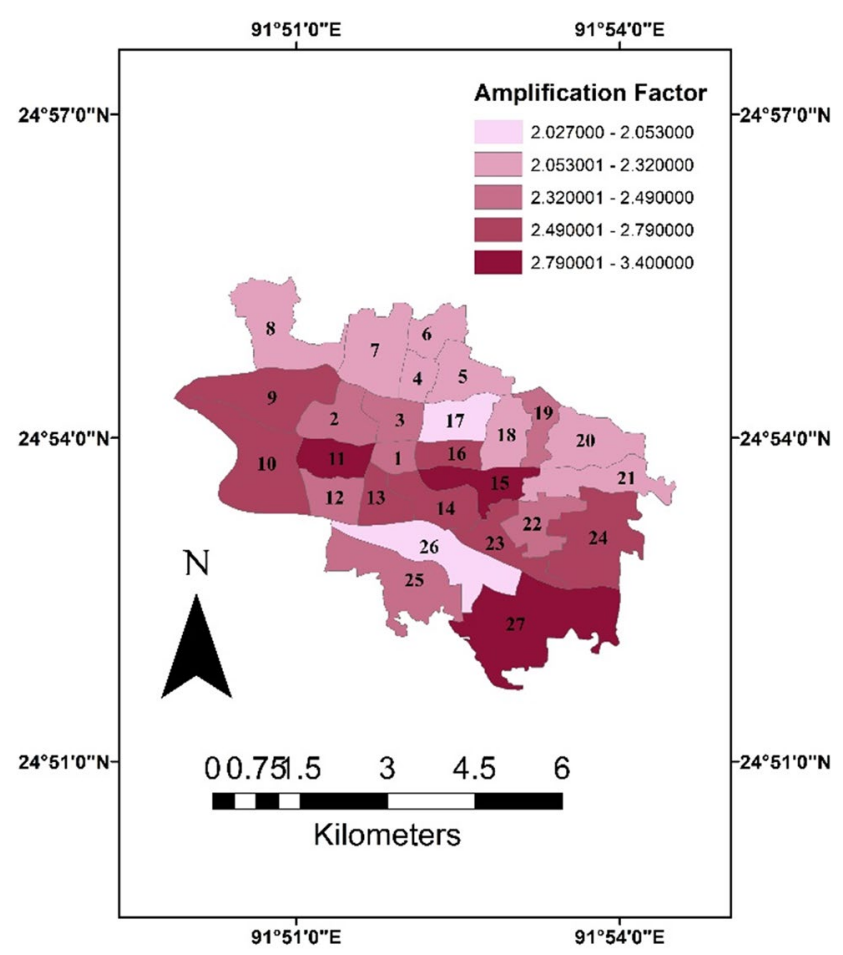

Fig. 5 Maximum AF value for 27 wards of Sylhet city corporation
The average shear wave velocity is calculated by the following equation [28]

$$
\mathrm{AVS}_{\mathrm{depth}}=\frac{d}{\sum_{i=1}^{n} \frac{h_{i}}{v_{i}}}
$$

where $h_{i}$ indicates a soil layer thickness (in meter), $d$ is the depth and $V_{i}$ is the ith layer's shear wave velocity in a total of $n$, that exists in-depth. Equation 6 gives the amplification factor, which is quite low as the amplification factor from another equation, but this equation provides a higher value in certain rare cases.

The amplification factor is calculated using an additional equation created by Raghu Kanth and lyengar [29]. This equation offers an amplification factor based on PGA and soil site class.

$\operatorname{Ln} F_{s}=a_{1} y_{b r}+a_{2}+\ln \delta_{s}$

where $a_{1}$ and $a_{2}$ are regression coefficient given in table and $y_{b r}$ is the spectral acceleration at the bedrock level and $\delta_{s}$ is the error term. The value of $\mathrm{a}_{1}, \mathrm{a}_{2}$ and $\delta_{s}$ is presented in the Table 3.

Site class $D$ is selected according to Table 2 for this study from the shear wave velocity. Surface acceleration values for site class $D$ can be achieved by multiplying the acceleration of the rock level by the amplification factor.

The amplification factor is calculated using an additional equation developed by Boore and Atkinson [31]. This equation offers an amplification factor that is only valid for shear wave velocity at a depth of $30 \mathrm{~m}$. In this study only, linear amplification is considered because nonlinear term produces no change relative to the linear term for low peak ground acceleration. The factor is measured by the next equation

$\operatorname{Ln} \mathrm{F}=\mathrm{c} * \ln \left(\frac{V_{s 30}}{V_{\text {ref }}}\right)$

In this research the $\mathrm{c}$ value is selected for period $0.5 \mathrm{~s}$ because for the weaker conditions of the site corresponding with the deeper site, the predominant duration for Sylhet city Corporation is about 0.23-0.75 s [32]. So, the value of $c=-0.9118$ and $V_{\text {ref }}=760 \mathrm{~m} / \mathrm{s}$ [31].

Table 3 Values for regression coefficients and the error term for various site classes [30]

\begin{tabular}{lrll}
\hline Site class & \multicolumn{1}{l}{$\mathrm{a}_{1}$} & $\mathrm{a}_{2}$ & \multicolumn{1}{l}{$\delta_{s}$} \\
\hline A & 0.00 & 0.36 & 0.03 \\
B & 0.00 & 0.49 & 0.08 \\
C & -0.89 & 0.66 & 0.23 \\
D & -2.61 & 0.80 & 0.36 \\
\hline
\end{tabular}

SN Applied Sciences A SPRINGER NATURE journa 


\section{Surface acceleration (SA)}

The most significant amplifying factor is selected over three amplifying factor equations. The surface acceleration is achieved by multiplying with the Peak ground acceleration value.

\section{Surface Acceleration $=\mathrm{PGA} * \mathrm{AF}$}

Figure 6 shows the value in each ward of Sylhet city of the amplification factor.

\section{Conversion of PGA to Modified Mercalli intensity (MMI)}

The effect of an earthquake is called intensity on the Earth surface [33]. Many intensity scales are available based on responses, such as awakening, furniture movement, damage in chimneys, or destruction. The Modified Mercalli intensity is now used extensively. A more meaningful scale than the magnitude has been given the Modified Mercalli intensity value assigned to a given site after an earthquake since the intensity refers to the effects experienced in that spot. The smaller intensity figures are usually concerned with the manner individuals feel the earthquake. The greater scale figures are based on the structural damage observed. Structural engineers generally provide data

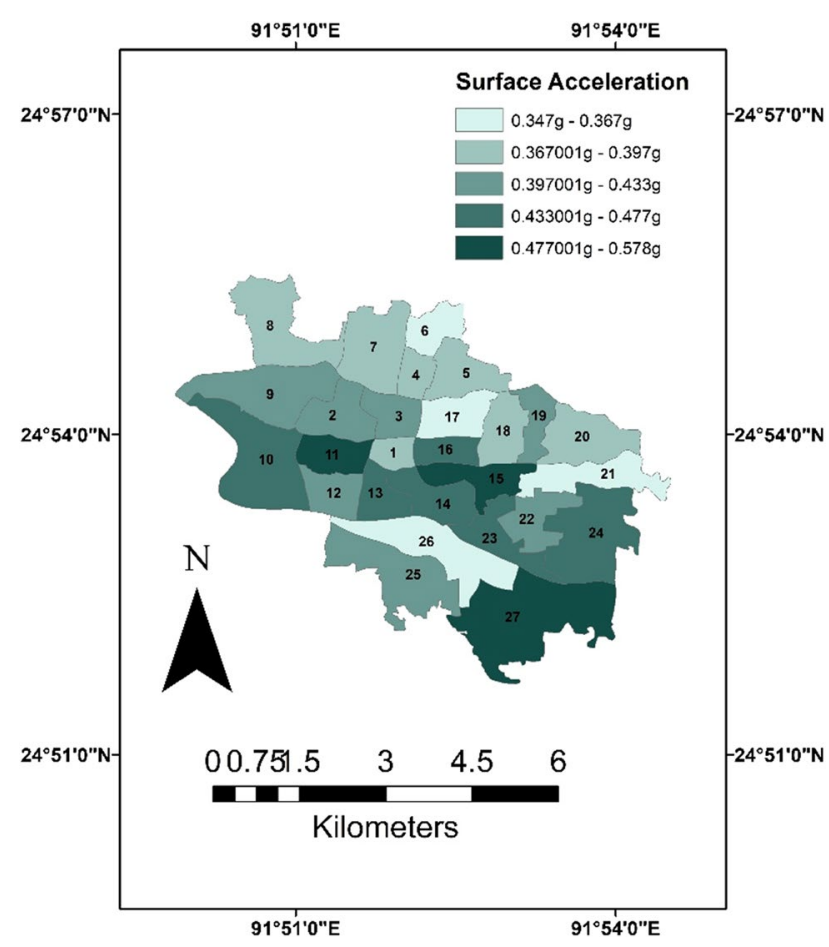

Fig. 6 SA value for 27 wards of Sylhet city corporation to assign VIII or higher intensity values [33]. Trifunac and Brady [34] are developing a connection between surface acceleration and MMI. The following equation calculates the MMI

$\log \left(\mathrm{PGA}_{\mathrm{s}}\right)=0.014+0.3(\mathrm{MMI})$

where PGAs $=$ Peak Ground Acceleration at the surface. $\mathrm{MMI}$ is calculated to show the seismic risk in the town of Sylhet. In the present research, the value of MMI is rounded to 0.5 , since the scale of MMI is a single integer. Figure 7 shows the MMI intensity for 27 wards of Sylhet city.

\section{Result and discussion}

In the construction, intensity maps play a significant role. It gives an understanding of the land of any given place and offers suggestions for structures. The purpose of this research is to send a message that every single word in Sylhet is Bangladesh's most sensitive zone. So, when building a structure, we should be more cautious. This research also aims to produce a methodology for preparing a map of intensity with the current equations.

With respect to the recurrence of the Srimangal earthquake in $1918,14.81 \%$ of the areas with PGA from 0.172 to $0.175 \mathrm{~g}, 18.51 \%$ with PGA $0.170-172 \mathrm{~g}, 25.93 \%$ with PGA from 0.168 to $170 \mathrm{~g}, 37.05 \%$ for PGA from 164 to $168 \mathrm{~g}$ and

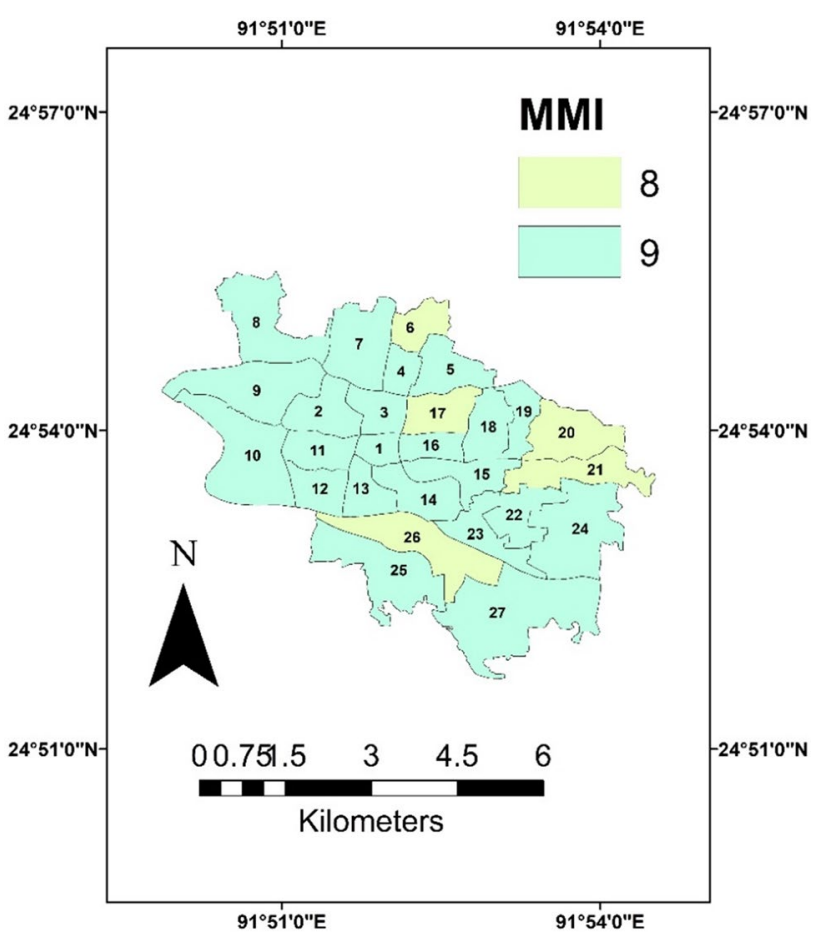

Fig. 7 MMI value for 27 wards of Sylhet city corporation 
PGA from $3.7 \%$ with PGA from $0.163 \mathrm{~g}$ will be affected. The results showed $11.11 \%$ of SA $0.47-0.57 \mathrm{~g}, 22.22 .0 \%$ of SA $0.43 \mathrm{~g}-0.47 \mathrm{~g}, 25.93 \%$ of SA $0.39-0.43 \mathrm{~g}, 25.93 \%$ with SS $0.36-0.39 \mathrm{~g}$ and $14.81 \%$ with SA $0.34-0.36 \mathrm{~g}$ are affected by the conversion of PGA to $S A$. When the SA has been transformed to $\mathrm{MMI}, 81.48 \%$ of intensity fields will be impacted and $18.52 \%$ with intensity VIII.

\section{Conclusion}

For the purpose of the Sylhet loss assessment, Ansary et al. [3] prepared a hazard map but no intensity map for each ward in Sylhet city. This research will therefore hopefully be working on a guideline for preparing intensity maps of any region with existing equations. Three GIS maps for the city of Sylhet are created, namely Peak Ground Acceleration, Amplification Factor, Surface Acceleration, and a final intensity map for the town of Sylhet. In the Modified Mercalli scale, peak regions will be impacted by intensity IX, which will cost massive harm in Sylhet city's maximum construction. Also, the NGA-West 2 model can be used as ground motion prediction equation for future studies.

\section{Compliance with ethical standards}

Conflict of interest On behalf of all authors, the corresponding author states that there is no conflict of interest.

\section{References}

1. Roy N et al (2002) The Gujarat earthquake (2001) experience in a seismically unprepared area: community hospital medical response. Prehospital Disaster Med 17(4):186-195

2. Avouac J-P et al (2006) The 2005, Mw 7.6 Kashmir earthquake: sub-pixel correlation of ASTER images and seismic waveforms analysis. Earth Planet Sci Lett 249(3-4):514-528

3. Ansary M, et al (2009) Loss assessment of Sylhet city from an event similar to 1918 Srimangal earthquake. In: Proceedings of the 17th international conference on soil mechanics and geotechnical engineering, Rotterdam. Millpress Science Publishers. https://doi.org/10.3233/978-1-60750-031-5-2715

4. Bilham R, Gaur VK, Molnar P (2001) Himalayan seismic hazard. Science 293(5534):1442-1444

5. Ahmed $S$ et al (2015) Earthquake vulnerability assessment of roads at Sylhet city in Bangladesh. Asian J Civ Eng (BHRC) 16(6):891-897

6. Ray S et al (2019) A study on b-value and investigation of seismic hazard in Sylhet seismic region, Bangladesh using Gumbel's extreme value distribution method. SN Appl Sci 1(5):435

7. Molnar P, Tapponnier P (1975) Cenozoic tectonics of Asia: effects of a continental collision. Science 189(4201):419-426

8. Sarker JK et al (2010) Potential losses for Sylhet, Bangladesh in a repeat of the 1918 Srimangal earthquake. Environ Econ 1(1):12-31
9. Kayal J et al (2006) Shillong plateau earthquakes in northeast India region: complex tectonic model. Curr Sci Bangalore 91(1):109

10. Le Dain AY, Tapponnier P, Molnar P (1984) Active faulting and tectonics of Burma and surrounding regions. J Geophys Res Solid Earth 89(B1):453-472

11. Sharfuddin M (2001) Earthquake hazard analysis for Bangladesh. MSc Engg. Unpublished Thesis, BUET, Dhaka

12. Sabri MS (2002) Earthquake intensity-attenuation relationship for Bangladesh and its surrounding region Masters Thesis, Department of Civil Engineering, Bangladesh University of Engineering and Technology, Dhaka

13. Sikder AM, Alam MM (2003) 2-D modelling of the anticlinal structures and structural development of the eastern fold belt of the Bengal Basin, Bangladesh. Sediment Geol 155(3-4):209-226

14. Alam MJ, Bhuiyan MAR, Islam MR (2006) Seismic structural assessment of damaged Chittagong public library building during 27 July 2003 earthquake. In: Proceedings of the 4th international conference on earthquake engineering, Taipei

15. Stuart M (1920) The Srimangal Earthquake of 8th July, 1918 Mem. Geol. Surv. India, XLVI, 1-70, Calcutta, India

16. Gutenberg B, Richter C (1954) Seismicity of the earth. Princeton University Press, Princeton, NJ, p 310

17. Hussien MN, Karray M (2015) Shear wave velocity as a geotechnical parameter: an overview. Can Geotech J 53(2):252-272

18. Lee SHH (1990) Regression models of shear wave velocities in Taipei basin. J Chin Inst Eng 13(5):519-532

19. Dikmen Ü (2009) Statistical correlations of shear wave velocity and penetration resistance for soils. J Geophys Eng 6(1):61-72

20. Ali B (2013) Estimation of linear site amplification by a ground motion prediction equation using results from a site survey. Pak J Meteorol 9(18):33-42

21. Boore DM (2004) Estimating $\bar{V}_{s}(30)$ (or NEHRP site classes) from shallow velocity models (depths $<30 \mathrm{~m}$ ). Bull Seismol Soc Am 94(2):591-597

22. UBC, B.S.S.C., Edition NEHRP Recommended Provisions for Seismic Regulations for New Buildings. Federal Emergency Management Agency, 1994

23. Boore DM, Joyner WB (1997) Site amplifications for generic rock sites. Bull Seismol Soc Am 87(2):327-341

24. Martin AJ, Diehl JG (2004) Practical experience using a simplified procedure to measure average shear-wave velocity to a depth of 30 meters (VS30). In: 13th World conference on earthquake engineering. International Association for Earthquake Engineering, Tokyo

25. McGuire RK (1978) Seismic ground motion parameter relations. $J$ Geotech Eng Div 104(4):481-490

26. Sarker JK (2011) GIS based methodologies of seismic Hazard and risk analysis for Bangladesh. PhD Hesis, Department of Civil Engg, BUET

27. Zangeneh $\mathrm{N}$, et al (2002) Application of response surface methodology in numerical geotechnical analysis. In: Proceedings of 55th Canadian society for geotechnical conference, Hamilton

28. Toni $M$ (2017) Simulation of strong ground motion parameters of the 1 June 2013 Gulf of Suez earthquake, Egypt. NRIAG J Astron Geophys 6(1):30-40

29. Kanth SR, lyengar R (2007) Estimation of seismic spectral acceleration in peninsular India. J Earth Syst Sci 116(3):199-214

30. Kolathayar S, Sitharam T, Vipin K (2012) Deterministic seismic hazard macrozonation of India. J Earth Syst Sci 121(5):1351-1364

31. Boore DM (2013) NGA-West2 equations for predicting response spectral accelerations for shallow crustal earthquakes. Pacific Earthquake Engineering Research Center

32. Hossain MS et al (2014) Predominant period and amplification factor estimation with respect to geomorphology-a case study 
of Sylhet city corporation area, Bangladesh. Bangladesh J Sci Res 27(1):1-10

33. USGS. 2017; Available from: https://earthquake.usgs.gov/learn /topics/mercalli.php

34. Trifunac M, Brady A (1975) On the correlation of seismic intensity scales with the peaks of recorded strong ground motion. Bull Seismol Soc Am 65(1):139-162
Publisher's Note Springer Nature remains neutral with regard to jurisdictional claims in published maps and institutional affiliations.

\section{SN Applied Sciences}

